\title{
A ultima parte demolida da antiga Academia de Direito
}

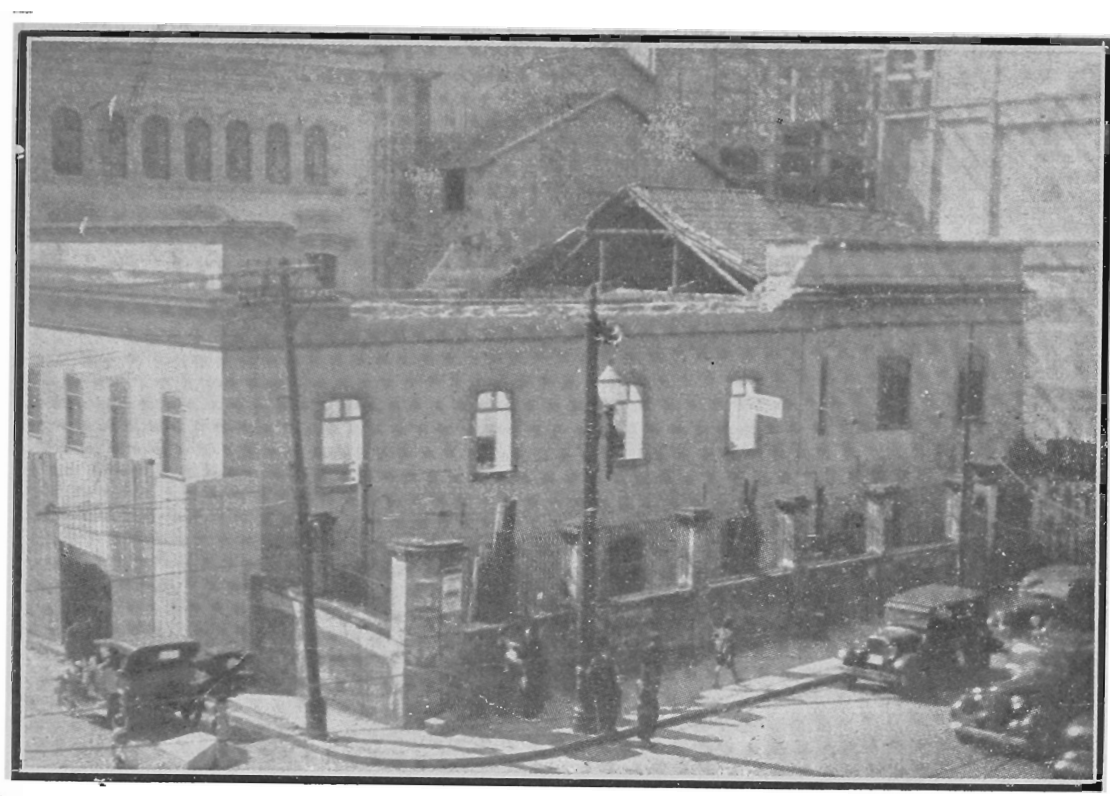

Já não existe nenhum trecho do prédio, onde funccionou a Academia de Direito, no largo de São Francisco. Para ceder o chão ao novo edificio, que se ergue na resistencia da alvenaria e do concreto, ruiram as Arcadas, desappareceram os corredores do Mosteiro, tombaram em poeira os salóes outróra cheios da voz dos Mestres.

Installou-se a Faculdade inteiramente na parte recem construida, embora ainda reste por ser concluida a metade do edificio.

O "cliché" estampado aqui focaliza os ultimos instantes dos derradeiros muros que cahiram sob a fúria das picaretas. Ultimas janellas que se escancararam no adeus ao passado.

Esse flagrante da demolição da Escola, fixou-o a objectiva dos estudantes que não largaram ao olvido as reminiscencias da tradição imperecivel.

No ponto photographado, angulo da rua do Riachuelo com a rua Christovam Colombo, está sendo levantado o amphitheatro da Faculdade de Direito. 